\title{
Nieprawidłowości w gospodarce finansowej jednostek samorządu terytorialnego ujawniane przez regionalne izby obrachunkowe - analiza za lata 2006-2014
}

\section{Streszczenie}

W artykule podjęto problematykę ujawnianych przez regionalne izby obrachunkowe (RIO) naruszeń prawa w wyniku przeprowadzonych kontroli gospodarki finansowej jednostek samorządu terytorialnego (JST). Dokonano także oceny skutków finansowych poszczególnych rodzajów stwierdzonych nieprawidłowości. Ze względu na skalę ujawnianych nieprawidłowości w artykule zwrócono uwagę na koncepcję kontroli zarządczej jako nowej kategorii prawa finansowego, której celem według założeń ustawodawcy jest wspomaganie realizacji założonych celów i zadań JST. Mając na uwadze dążenie do ograniczenia czynników ryzyka powstawania nieprawidłowości, przedstawiono istotę mechanizmów kontroli w działaniu gospodarki finansowej.

Celem artykułu jest przedstawienie najczęściej ujawnianych przez RIO naruszeń prawa w działaniu gospodarki finansowej JST. Skoncentrowano się w nim na przeglądzie literatury przedmiotu, a także sprawozdań z działalności RIO przygotowanych przez Krajową Radę Regionalnych Izb Obrachunkowych. Realizacja tak założonego celu badawczego wymagała także wtórnej analizy uregulowań prawnych. Badania obejmowały lata 2006-2014, a więc okres wprowadzania gruntownych zmian w przepisach prawa finansowego.

Piotr Sołtyk, Uniwersytet Ekonomiczny w Krakowie, Katedra Finansów Samorządowych, 31-510 Kraków, ul. Rakowicka 27, e-mail: piotr.soltyk@uek.krakow.pl 
Słowa kluczowe: samorząd terytorialny, kontrola finansowa, regionalna izba obrachunkowa, nieprawidłowości.

Klasyfikacja JEL: H83, H61.

\section{Wprowadzenie}

Realizacja zadań przez samorząd terytorialny oparta jest na publicznym zasobie finansowym. Ustanowienie nadzoru i kontroli gospodarki finansowej jednostek samorządu terytorialnego (JST) leży w interesie państwa, a także mieszkańców wspólnoty lokalnej lub regionalnej (por. [Chojna-Duch 2003, s. 232]). Organem uprawnionym do kontroli działania gospodarki finansowej JST są regionalne izby obrachunkowe (RIO). Kontrola realizowana przez ten konstytucyjnie umocowany organ stanowi immanentną funkcję zarządzania. Służy to nie tylko ochronie mienia publicznego przed nieuzasadnionymi stratami, ale również ujawnieniu naruszenia prawa, a następnie wskazaniu kierunków poprawy w ramach zaleceń pokontrolnych, co wpływa na jakość zarządzania gospodarką finansową JST (por. [Kałużny i Zawadzak 1999, s. 9]). RIO wskazują dysfunkcje i ujawniają luki w działaniu systemu kontroli zarządczej oraz pozwalają na podejmowanie działań na przyszłość mających na celu ograniczenie naruszeń prawa.

Celem artykułu jest przedstawienie najczęściej ujawnianych przez RIO naruszeń prawa w działaniu gospodarki finansowej JST. Jako metodę badawczą przyjęto przegląd literatury przedmiotu, a także sprawozdań z działalności RIO przygotowanych przez Krajową Radę Regionalnych Izb Obrachunkowych. Realizacja tak założonego celu badawczego wymagała także wtórnej analizy uregulowań prawnych. Badania obejmowały lata 2006-2014, a więc okres wprowadzania gruntownych zmian w przepisach prawa finansowego. Uzyskane wyniki z badań pozwalają wskazać obszary gospodarki finansowej, w których najczęściej ujawniane są przypadki naruszenia prawa. W praktyce przedmiotowa informacja może być wykorzystana do planowania, organizowania i ewaluacji działania gospodarki finansowej JST.

\section{Regionalne izby obrachunkowe w systemie kontroli finansów publicznych}

Decentralizacja administracji publicznej spowodowała konieczność powołania organów, które sprawować będą nadzór i kontrolę nad legalnością działań samorządów terytorialnych (por. [Kosek-Wojnar i Surówka 2007, s. 252]). Początki działania RIO związane są z przepisami ustawy z dnia 8 marca $1990 \mathrm{r}$. o samorządzie gminnym. W art. 86 tej ustawy wskazano bowiem, że nadzór 
nad działalnością gmin w zakresie spraw budżetowych prowadzić będą RIO jako niezależne od wojewody instytucje. Wraz z wejściem w życie tego przepisu wojewoda pozbawiony został możliwości sprawowania nadzoru i kontroli nad finansami gmin. W konstrukcji systemu kontroli środków publicznych RIO jako organy państwowe utworzone zostały na podstawie ustawy z dnia 7 października 1992 r. Ustawa weszła jednak w życie dopiero 1 stycznia 2003 r. Wskazać należy, że RIO jako organy państwowe wyróżnione zostały w przepisach ustawy zasadniczej jako niezbywalny element ustroju Polski [Dębowska-Romanowska 2007, s. 4]. W świetle dyspozycji art. 171 Konstytucji RP „działalność samorządu terytorialnego podlega nadzorowi z punktu widzenia legalności, zaś organami nadzoru nad działalnością jednostek samorządu terytorialnego są Prezes Rady Ministrów i wojewodowie, a w zakresie spraw finansowych - regionalne izby obrachunkowe". Konstytucja traktuje RIO jako wyspecjalizowane organy nadzoru i kontroli nad działalnością JST w zakresie spraw finansowych, a także wyraźnie oddziela nadzór wykonywany przez administrację rządową od nadzoru realizowanego przez RIO (por. [„Informator” 2007, s. 6]). Jak podkreśla B. Filipiak, ,jednym z ważniejszych ogniw w procesie kontroli administracji publicznej są RIO, które w szczególności nadzorują i kontrolują gospodarkę finansową JST" [2007, s. 83]. Z uregulowań ustawy o RIO wynika, że wykonują one dwie zasadnicze funkcje wobec samorządu terytorialnego, tj. nadzór i kontrolę gospodarki finansowej. Pierwsza funkcja - nadzór nad samorządem terytorialnym, może być realizowana pod kątem zgodności z prawem, legalności. Dodać należy, że RIO mogą prowadzić wyłącznie nadzór w przypadkach wynikających z przepisów rangi ustawowej. Przedmiotem nadzoru są uchwały i zarządzenia podejmowane przez przedstawicieli organu stanowiącego, organ wykonawczy, a także związki komunalne utworzone przez JST. Zgodnie z dyspozycją art. 11 ustawy o RIO w zakresie działalności nadzorczej Izby badają sprawy dotyczące:

- procedury uchwalania budżetu i jego zmian,

- budżetu i jego zmian,

- zaciągania zobowiązań wpływających na wysokość długu publicznego JST oraz udzielania pożyczek,

- zasad i zakresu przyznawania dotacji z budżetu JST,

- podatków i opłat lokalnych, do których mają zastosowanie przepisy ordynacji podatkowej,

- absolutorium,

- wieloletniej prognozy finansowej i jej zmian.

Oprócz działalności nadzorczej RIO przeprowadzają kontrolę gospodarki finansowej JST. Funkcja kontrolna sprawowana przez Izbę jest bardziej rozbudowana. Obejmuje ona pokaźny krąg podmiotów zaliczanych do sektora finansów publicznych. Przedmiotem zainteresowania RIO są również podmioty niezaliczane 
do sektora finansów publicznych, np. stowarzyszenia, fundacje, które dysponują środkami publicznymi przekazanymi w formie transferów pieniężnych - dotacji celowych z budżetów samorządowych. Środki te przekazywane są na realizację zadań własnych JST, muszą więc podlegać szczegółowej kontroli w zakresie prawidłowości ich wykorzystania. Izby przeprowadzają kontrolę gospodarki finansowej JST, w tym także wnikliwej ocenie podlega realizacja zobowiązań podatkowych. Przedmiotem kontroli RIO jest również zgodność z prawem zamówień publicznych. Przepisy prawa zobowiązują Izbę do przeprowadzenia, co najmniej raz na 4 lata, kontroli kompleksowej w JST (art. 7 ustawy o RIO). Ten rodzaj kontroli charakteryzuje się tym, że jej przedmiotem jest całokształt działania gospodarki finansowej JST. Zakres kontroli kompleksowej jest jednolity dla wszystkich RIO w Polsce i obejmuje (por. [Uchwała nr 3/2001]):

- ustalenia ogólnoorganizacyjne, w tym działanie kontroli zarządczej,

- prowadzenie księgowości i sporządzanie sprawozdań budżetowych,

- gospodarkę pieniężną i rozrachunki, w tym zadłużenie jednostek,

- realizację dochodów budżetowych,

- dokonywanie wydatków budżetowych,

- gospodarowanie mieniem komunalnym,

- rozliczenia finansowe JST z jej jednostkami organizacyjnymi,

- realizację zadań z zakresu administracji rządowej zleconych i powierzonych JST.

Oprócz kontroli kompleksowych Izby mogą przeprowadzać w administracji samorządowej również inne rodzaje kontroli. Są to kontrole problemowe i doraźne. Dodać należy, że tego rodzaju kontroli ustawodawca nie wymienił w treści Ustawy z dnia 7 października 1992 r. o regionalnych izbach obrachunkowych, lecz wskazał je dopiero w przepisach Rozporządzenia Prezesa Rady Ministrów z dnia 16 lipca 2004 r. w sprawie siedzib i zasięgu terytorialnego regionalnych izb obrachunkowych oraz szczegółowej organizacji izb, liczby członków kolegium i trybu postępowania.

Kontrole problemowe obejmują jedynie wybrane zagadnienia w jednej lub kilku JST. Kontrole doraźne wyróżniają się tym, że są podejmowane w razie potrzeby. Dodatkowo prezes RIO może zarządzić przeprowadzenie kontroli, której przedmiotem jest sprawdzenie stopnia realizacji zaleceń pokontrolnych wydanych po przeprowadzonej wcześniej kontroli.

Podczas kontroli RIO badana jest zgodność z prawem, a także zgodność dokumentacji ze stanem faktycznym. Podstawowym kryterium, na podstawie którego RIO przeprowadza kontrolę, jest legalność. W literaturze przedmiotu kryterium to określane jest często jako metakryterium, czyli kryterium dominujące nad innymi [Kasiński i in. 1994, s. 38]. Przez legalność należy rozumieć „zgodność 
z obowiązującymi w badanym okresie przepisami konstytucji, ustaw, ratyfikowanych umów międzynarodowych, rozporządzeń, aktów prawa miejscowego oraz przepisów wewnętrznych" [Glosariusz terminów... 2005]. Zastosowanie kryterium zgodności z prawem oznacza każdorazowo konieczność przyrównywania zastanego sposobu zachowania z wzorcem, czyli oceny, czy prawo jest stosowane właściwie [Cybulski 2010, s. 77].

Przedstawiciele RIO badają działalność gospodarki finansowej JST także na podstawie kryterium rzetelności. Rzetelność rozumiana jest jako „wypełnianie obowiązków z należytą starannością, sumiennie i we właściwym czasie, wypełnianie zobowiązań zgodnie $\mathrm{z}$ ich treścią, przestrzeganie wewnętrznych reguł funkcjonowania danej jednostki - w szczególności określonego dla poszczególnych komórek i osób zakresu obowiązków" [Glosariusz terminów... 2005].

Ustawodawca upoważnił inspektorów RIO do uwzględnienia w trakcie kontroli także kryterium celowości i gospodarności, ale kryteria te mogą być zastosowane wyłącznie do kontroli w zakresie zadań administracji rządowej, które są wykonywane przez JST na podstawie ustaw lub zawartych porozumień. Celowość to kryterium, według którego ocenia się, czy jednostka realizuje postawione przed nią cele [Glosariusz terminów... 2005]. Przez cele jednostki należy rozmieć zarówno ogólne odniesienie do zakresu przydzielonych jej do realizacji zadań (ustawowych, statutowych) wynikających z aktu założycielskiego, jak też cele określone dla poszczególnych sfer działalności, programów, zamierzeń jednostki [Glosariusz terminów... 2005]. W systemie kontroli finansów publicznych gospodarność obok zasady działania w zgodności z prawem stanowi kluczowe kryterium oceny. Obowiązek respektowania zasady gospodarności wyrażony został w dyspozycji art. 44 Ustawy z dnia 27 sierpnia 2009 r. o finansach publicznych przez zobowiązanie kierowników, jako osób odpowiedzialnych za całość gospodarki finansowej jednostek, m.in. do dokonywania wydatków publicznych w sposób celowy i oszczędny z uwzględnieniem efektów z poniesionych nakładów. W literaturze przedmiotu spotkać można stwierdzenie, że kryterium gospodarności tkwi we wszystkich kryteriach kontroli jako ich integralny element [Kurowski, Ruśkowski i Sochacka-Krysiak 2000, s. 48-49]. Potocznie zasada gospodarności odnosi się do badania, którego celem jest ustalenie, czy zarząd JST w sposób oszczędny zarządzał środkami publicznymi oraz mieniem komunalnym. Zasada ta zobowiązuje także decydentów samorządowych do podejmowania działań nadzorczych mających na celu niedopuszczenie do wystąpienia szkód w przyszłej działalności JST. 


\section{Kontrola zarządcza jako instrument wspomagający realizacje celów i zadań jednostek samorządu terytorialnego}

Pojęcie kontroli zarządczej pojawiło się w systemie finansów publicznych w wyniku zmiany Ustawy z dnia 30 czerwca 2005 r. o finansach publicznych. Jak wynika z uzasadnienia do rządowego projektu ustawy o finansach publicznych z 2009 r., ,wprowadzenie pojęcia kontroli zarządczej w jednostkach sektora finansów publicznych w miejsce obecnego terminu - kontrola finansowa, wynika z faktu, że dotychczasowa praktyka związana z funkcjonowaniem w przepisach pojęcia kontroli finansowej pokazuje, iż jest ona utożsamiana wyłącznie z czysto finansowym aspektem działalności jednostki. Zamierzeniem projektodawcy było objęcie zakresem kontroli zarządczej wszystkich aspektów działalności jednostki" [Uzasadnienie do rządowego projektu... 2009]. W przeciwieństwie do kontroli finansowej ideą kontroli zarządczej jest nowatorskie podejście do zarządzania organizacją publiczną na wzór działania podmiotów korporacyjnych. W systemie kontroli zarządczej wyraźnie uwypukla się odpowiedzialność każdego kierownika JST za zaprojektowanie, wdrożenie, a następnie stałe monitorowanie realizacji założonych celów i zadań ${ }^{1}$. Planowanie oraz wyznaczenie celów i zadań, a następnie rozliczanie osób odpowiedzialnych za ich realizację lub zaniechanie jest jednym z filarów koncepcji kontroli zarządczej.

Ustawodawca pojęcie kontroli zarządczej zdefiniował bardzo ogólnie w art. 68 ustawy o finansach publicznych. Według tego przepisu stanowi ona ogół działań podejmowanych, by zapewnić realizację celów i zadań w sposób zgodny z prawem, efektywny, oszczędny i terminowy. Natomiast szczegółowe cele kontroli zarządczej wymienione zostały w art. 68 ust. 2 ustawy o finansach publicznych. Należy zwrócić uwagę, że określone przez ustawodawcę cele stanowią katalog otwarty i obejmują w szczególności:

- zgodność działalności z przepisami prawa oraz procedurami wewnętrznymi,

- skuteczność i efektywność działania,

- wiarygodność sprawozdań,

- ochronę zasobów,

- przestrzeganie i promowanie zasad etycznego postępowania,

- efektywność i skuteczność przepływu informacji,

- zarządzanie ryzykiem.

Koncepcji kontroli zarządczej nie należy utożsamiać z czynnościami stricte kontrolnymi. Mimo że użyto słowa „kontrola”, nie jest uprawnione łączenie dzia-

${ }^{1}$ Według art. 69 ust. 2 ustawy o finansach publicznych zapewnienie funkcjonowania adekwatnej, skutecznej i efektywnej kontroli zarządczej należy do obowiązków wójta, burmistrza, prezydenta miasta, przewodniczącego zarządu jednostki samorządu terytorialnego. 
łania kontroli zarządczej z kontrolą finansową. Trzeba podkreślić, że koncepcja kontroli zarządczej jest znacznie szersza, gdyż obejmuje kompleksowo działanie JST. Nieuprawnione jest zatem ograniczanie jej wyłącznie do czynności polegających na wskazywaniu nieprawidłowości i osób, które przyczyniły się do ich powstania. Ujawnienia różnego rodzaju dysfunkcji w działaniu gospodarki finansowej i poszukiwanie nowatorskich rozwiązań ograniczających ich występowanie w przyszłości jest ważne, ale nie jest to zasadniczy cel sytemu kontroli zarządczej. Cele takie stawiane są przed kontrolą finansową, która to aktualnie jest jednym $\mathrm{z}$ wielu, ale bardzo ważnych elementów systemu kontroli zarządczej. Kontrola zarządcza jest systemem bardziej złożonym, który ma za zadanie sprawić, aby samorządowa jednostka organizacyjna i JST osiągnęły cele przed nimi postawione [Kontrola zarządcza... 2010]. Spotkać można także opinie, że kontrolę zarządczą należy wiązać z zarządzaniem jednostką lub grupą jednostek, zaś za najistotniejszy jej element trzeba uznać system wyznaczania celów i zadań oraz monitorowanie stopnia ich realizacji [Kontrola zarządcza... 2011, s. 3].

Podkreślić należy, że dla skuteczności działania gospodarki finansowej bez generowania w niej poważnych dysfunkcji w koncepcji kontroli zarządczej istotne znaczenie ma umiejętność zarządzania ryzykiem. Zarządzanie ryzykiem jest jednym $\mathrm{z}$ wielu celów kontroli zarządczej². Jest to działanie, które z pewnością wymaga przede wszystkim zmiany sposobu kierowania JST przez decydentów samorządowych. W sektorze publicznym zarządzanie ryzykiem ma służyć minimalizowaniu ryzyka mogącego zagrozić realizacji celów i zadań ważnych dla mieszkańców danej wspólnoty samorządowej.

Aby skutecznie ograniczyć możliwość pojawienia się dużego ryzyka nieprawidłowości w gospodarce finansowej, należy zadbać, by zarządzanie ryzykiem nie polegało jedynie na wprowadzeniu w JST kilku pisemnych procedur. Procedury wewnętrzne w jednostce są ważne, ale stanowią one tylko narzędzie, które elastycznie wspomagają kierownictwo w procesie zarządzania ryzykiem. Uregulowania wewnętrzne, aby istotnie ograniczały ryzyko nieprawidłowości, muszą być spójne z profilem działania jednostki, jak również powinny być na bieżąco uaktualniane i poddawane ewaluacji w celu ustalenia w nich ewentualnych luk ${ }^{3}$. O sukcesie zarządzania ryzykiem współcześnie decyduje przede wszystkim szybka umiejętność identyfikowania i szacowania czynników ryzyka - potencjalnych zdarzeń, które mogą zakłócić realizację założonych celów. Efektywne zarządzanie ryzykiem na płaszczyźnie JST wymaga spełnienia czterech warunków [Czerwiński 2003, s. 82]:

${ }^{2}$ Zgodnie z art. 68 ust. 2 ustawy o finansach publicznych zarządzanie ryzykiem stanowi cel kontroli zarządczej.

${ }^{3}$ Zgodnie z art. 10 ust. 2 Ustawy z dnia 29 września 1994 r. o rachunkowości kierownik jednostki aktualizuje przyjęte zasady (politykę) rachunkowości. 
- polityka i korzyści wynikające z zarządzania ryzykiem powinny być znane wszystkim pracownikom,

- kierownictwo wyższego szczebla powinno wspierać działania w zakresie zarządzania ryzykiem,

- zarządzanie ryzykiem powinno być integralną częścią procesu zarządzania gospodarką finansową JST,

- zarządzanie ryzykiem powinno być ściśle powiązane z przyjętymi do realizacji celami i zadaniami.

Za ograniczenie skutków ryzyka odpowiedzialność ponosi wyłącznie kierownik JST, dlatego tak ważne jest, aby decydenci samorządowi posiadali umiejętność szybkiego identyfikowania ryzyka i podejmowania działań zaradczych. Dodać należy, że kwalifikacje kierownika JST, a także personelu pracowniczego w zakresie skutecznego zarządzania ryzykiem niejednokrotnie chronią przed pojawieniem się dużego ryzyka skutkującego naruszeniem dyscypliny finansów publicznych. Obszerny katalog czynów skutkujących naruszeniem dyscypliny finansów publicznych w związku z niewykonaniem lub nienależytym wykonaniem przez kierownika jednostki obowiązków w zakresie kontroli zarządczej wymieniony został w treści art. 18 c Ustawy z dnia 17 grudnia 2004 r. o odpowiedzialności za naruszenie dyscypliny finansów publicznych. O tym, że zarządzanie ryzykiem w administracji samorządowej jest mało efektywne i nie w pełni odpowiada wymogom prawa, a także wytycznym standardów kontroli zarządczej [Komunikat nr 23... 2009] informowała NIK już w 2011 r. po przeprowadzeniu w wybranych JST kontroli, której przedmiotem było „funkcjonowanie kontroli zarządczej w JST ze szczególnym uwzględnieniem audytu wewnętrznego" [Informacja o wynikach kontroli... 2011]. Jako przyczynę braku realizacji wymogów ustawy o finansach publicznych w zakresie zarządzania ryzykiem kierownicy JST podawali to, że proces zarządzania ryzykiem jest zagadnieniem nowym, wymagającym doświadczenia oraz korzystania z dobrych, skutecznych i sprawdzonych rozwiązań (zob. szerzej [Informacja o wynikach kontroli... 2011, s. 16]). Argumentacja decydentów JST jest mało przekonująca, gdyż z raportu NIK wynika, że aż 70\% kierowników skontrolowanych urzędów w ogóle nie uczestniczyło w szkoleniach z zakresu zarządzania ryzykiem [Informacja o wynikach kontroli... 2011, s. 16]. Złożoność systemu zarządzania ryzykiem wymaga od kierowników JST ciągłego doskonalenia, w szczególności w zakresie identyfikacji, oceny, monitorowania i przeciwdziałaniu skutkom materializacji ryzyka. Nabycie tych umiejętności pozwoli decydentom samorządowym na podejmowanie właściwych decyzji zarządczych ograniczających powstawanie różnych nieprawidłowości w działaniu gospodarki finansowej JST. Zminimalizowanie czynników ryzyka prowadzących do naruszenia prawa może nastąpić po wdrożeniu w JST systemu zarządzania 
ryzykiem. System ten powinien uwzględniać w szczególności: (por. [Jastrzębska, Janowicz-Lomott i Łyskawa 2014, s. 173-174]):

- rodzaj i wielkość JST oraz poziom rozwoju JST,

- warunki, w jakich działa JST, zwłaszcza prawne i ekonomiczne,

- cele i zadania JST,

- zasoby JST (np. rzeczowe, kadrowe, informatyczne),

- strukturę organizacyjną JST i sposób, w jaki zarządza się JST, zwłaszcza poziom rozwoju i złożoność systemów funkcjonujących w JST, tj. systemów zarządczych, systemów IT, systemów finansowo-księgowych,

- liczbę i rodzaj jednostek organizacyjnych JST i liczbę zatrudnionych w nich pracowników,

- kondycję finansową, bieżącą i historyczną, potencjał dochodowy JST, atrakcyjność inwestycyjną i stopień samodzielności finansowej,

- oczekiwania i potrzeby zgłaszane przez kierownictwo związane z wdrażaniem systemu zarządzania ryzykiem,

- częstotliwość i szczegółowość przeprowadzania samooceny działania gospodarki finansowej JST,

- skuteczność i efektywność działania audytu wewnętrznego w JST zobowiązanych do jego wprowadzenia.

Należy także podkreślić, że skuteczne ograniczenie ryzyka związanego z występowaniem nieprawidłowości w działaniu gospodarki finansowej może nastąpić po zaprojektowaniu i wdrożeniu stosownych mechanizmów kontroli tworzących spójny system kontroli zarządczej. Ograniczenie czynników ryzyka powodujących powstawanie nieprawidłowości jest możliwe przez skuteczne wykorzystanie określonych metod zarządzania ryzykiem. Powszechnie stosowaną techniką w samorządzie terytorialnym jest metoda ścieżki krytycznej (critical path analysis), za pomocą której na bieżąco śledzi się zmiany w realizowanych zadaniach publicznych, co umożliwia skuteczne zarządzanie ryzykiem i następnie podejmowanie działań redukujących jego materializację. Drugą często stosowaną metodą pozwalającą określić przyczyny odstępstw od stanu optymalnego (zakładanego) jest diagram Ishikawy. Istotą tego diagramu jest określenie przyczyn powstania danej niezgodności, a następnie przeprowadzanie analizy pozwalającej rozwiązać problem.

\section{Ujawnione przez regionalne izby obrachunkowe naruszenia prawa}

$\mathrm{Z}$ danych zawartych w tabeli 1 wynika, że w okresie objętym badaniami inspektorzy RIO najwięcej przypadków nieprawidłowości ujawnili w 2008 r. (17 171), a najmniej w 2014 r. (14 035). Przeprowadzone badania pozwoliły stwierdzić, że 
największa liczba ujawnionych nieprawidłowości dotyczyła realizacji budżetu. Nieprawidłowości w tym obszarze w 2007 r. stanowiły ponad 39\%, a w 2014 r. $29 \%$ ujawnionych naruszeń prawa. W pozostałych latach nieprawidłowości w tym obszarze wynosiły średnio $31 \%$.

Na potrzeby analizy nieprawidłowości związane z wykonaniem budżetu podzielone zostały na trzy grupy, tj. zagadnienia ogólne dotyczące planowania i realizacji budżetu, dochody i przychody oraz wydatki i rozchody.

Do najczęściej ujawnianych przypadków naruszeń regulacji prawnych w zakresie planowania i realizacji budżetu należy zaliczyć (zob. szerzej [Sprawozdania z działalności... 2006-2014]:

- nieterminowe regulowanie zobowiązań,

- niesporządzanie lub nieprawidłowe sporządzanie planów finansowych oraz nieaktualizowanie tych planów,

- niedozwolone finansowanie budżetu danego roku (np. ratą części subwencji oświatowej na rok następny, środkami ZFŚS, depozytowymi).

Najczęściej ujawniane nieprawidłowości w zakresie dochodów i przychodów budżetu to (zob. szerzej [Sprawozdania z działalności... 2006-2014]):

- nieweryfikowanie lub nierzetelne weryfikowanie deklaracji podatkowych (podatek od nieruchomości, podatek rolny, podatek leśny, podatek od środków transportowych),

- ustalanie lub określanie wysokości zobowiązania podatkowego niezgodnie z obowiązującymi przepisami lub uchwałami rady gminy (podatek od nieruchomości, podatek rolny, podatek leśny, podatek od środków transportowych),

- niewłaściwe podejmowanie lub zaniechanie czynności zmierzających do zastosowania środków egzekucyjnych (zaległości z tytułu podatków i opłat),

- nieprzestrzeganie przepisów Ustawy z dnia 29 sierpnia 1997 r. - Ordynacja podatkowa przy udzielaniu ulg w zapłacie podatków (podatek od nieruchomości, podatek rolny, podatek leśny, podatek od środków transportowych),

- niezachowanie zasady powszechności opodatkowania (podatek od nieruchomości, podatek rolny, podatek leśny, podatek od środków transportowych),

- wykazywanie w sprawozdaniach nieprawidłowych skutków udzielonych ulg, zwolnień i obniżek stawek podatkowych.

Natomiast w zakresie wydatków i rozchodów budżetu do najczęściej ujawnianych przypadków naruszeń prawa trzeba zaliczyć (zob. szerzej [Sprawozdania z działalności... 2006-2014]):

- niezgodne z obowiązującymi przepisami ustalanie i wypłacanie wynagrodzeń pracownikom,

- nieprawidłowości przy rozliczaniu kosztów podróży służbowych,

- przekroczenie upoważnienia do dokonywania wydatków,

- brak kontrasygnaty skarbnika na zawieranych umowach, 
- nieprawidłowości w zakresie ustalania i wypłaty jednorazowych dodatków uzupełniających dla nauczycieli,

- nieprawidłowe naliczanie lub nieterminowe przekazywanie odpisów na ZFŚS,

- przekroczenie upoważnienia do zaciągania zobowiązań,

- nieterminowe opłacanie składek na Fundusz Ubezpieczeń Społecznych i Fundusz Pracy, zaliczek na podatek dochodowy od osób fizycznych.

Równie duża liczba nieprawidłowości ujawniona została w zakresie księgowości i sprawozdawczości. Najwięcej przypadków naruszeń prawa stwierdzono w 2014 r. - 4238 przypadków, co stanowi 30\% wszystkich nieprawidłowości. $\mathrm{W}$ pozostałych latach nieprawidłowości w tym obszarze wynosiły ponad $25 \%$ ogółem ujawnionych dysfunkcji. Najczęściej stwierdzane naruszenia prawa dotyczyły (zob. szerzej [Sprawozdania z działalności... 2006-2014]):

- nieprawidłowego stosowania klasyfikacji budżetowej dochodów i wydatków,

- wykazywania w sprawozdaniach danych niezgodnych z ewidencją księgową,

- nierzetelnego prowadzenia ksiąg rachunkowych,

- nieprowadzenia wszystkich wymaganych przepisami ustawy o rachunkowości ksiąg rachunkowych, w tym dziennika, kont analitycznych i zestawien obrotów i sald.

Z danych zawartych w tabeli 1 wynika, że duża liczba ujawnionych nieprawidłowości dotyczy również zagadnień ogólnoorganizacyjnych. Najwięcej nieprawidłowości ujawniono w 2006 r. - 2064 przypadków, tj. 12\% ogółem. W okresie objętym badaniami średnia liczba naruszeń prawa w tej kategorii wynosiła $10 \%$ wszystkich ujawnionych nieprawidłowości. Naruszenia prawa dotyczące zagadnień ogólnoorganizacyjnych to w szczególności (zob. szerzej [Sprawozdania z działalności... 2006-2014]):

- brak dokumentacji opisującej przyjęte zasady rachunkowości lub niewłaściwe jej opracowanie (w tym np. zakładowego planu kont, wykazu stosowanych ksiąg rachunkowych, dokumentacji systemu przetwarzania danych przy użyciu komputera),

- niestosowanie mechanizmów kontroli zarządczej lub ich nieprawidłowe stosowanie,

- niewykonanie wniosków pokontrolnych,

- nieprzestrzeganie procedur kontroli,

- prowadzenie działalności kulturalnej w niewłaściwej formie (niezgodnie ze statutem, w formie innej niż instytucja kultury lub w połączeniu z inną instytucją kultury),

- zaniechanie audytu w jednostce do tego zobowiązanej,

- nieudzielenie kierownikom jednostek organizacyjnych pełnomocnictw do jednoosobowego działania,

- nieokreślenie formy organizacyjnoprawnej jednostek organizacyjnych. 
Tabela 1. Nieprawidłowości ujawniane przez RIO w poszczególnych obszarach gospodarki finansowej w latach 2006-2014

\begin{tabular}{|c|c|c|c|c|c|c|c|c|c|}
\hline Wyszczególnienie & 2006 & 2007 & 2008 & 2009 & 2010 & 2011 & 2012 & 2013 & 2014 \\
\hline Ogółem & 16549 & 15876 & 17171 & 16663 & 16481 & 15819 & 15930 & 14277 & 14035 \\
\hline $\begin{array}{l}\text { Ustalenia organiza- } \\
\text { cyjne }\end{array}$ & 2064 & 1916 & 1862 & 1833 & 1552 & 1282 & 1373 & 1214 & 1263 \\
\hline $\begin{array}{l}\text { Księgowość i spra- } \\
\text { wozdawczość }\end{array}$ & 3462 & 3196 & 3596 & 3515 & 4505 & 4290 & 4535 & 4184 & 4238 \\
\hline $\begin{array}{l}\text { Gospodarka } \\
\text { pieniężna i rozra- } \\
\text { chunki }\end{array}$ & 1613 & 1070 & 166 & 1102 & - & - & - & - & - \\
\hline $\begin{array}{l}\text { Wykonanie } \\
\text { budżetu, w tym }\end{array}$ & 5789 & 6238 & 6404 & 6123 & 5882 & 6143 & 5955 & 5172 & 5098 \\
\hline $\begin{array}{l}\text { - ogólne zagadnie- } \\
\text { nia dotyczące pla- } \\
\text { nowania i wyko- } \\
\text { nania budżetu }\end{array}$ & 185 & 231 & 196 & 216 & 147 & 535 & 567 & 550 & 552 \\
\hline $\begin{array}{l}\text { - dochody i przy- } \\
\text { chody }\end{array}$ & 3285 & 3726 & 3759 & 3389 & 3608 & 3560 & 3289 & 3012 & 2881 \\
\hline $\begin{array}{l}\text { - wydatki i roz- } \\
\text { chody }\end{array}$ & 2319 & 2281 & 2449 & 2518 & 2127 & 2048 & 2099 & 1610 & 1665 \\
\hline $\begin{array}{l}\text { Zamówienia } \\
\text { publiczne }\end{array}$ & 2032 & 1972 & 2339 & 2157 & 2306 & 1908 & 1830 & 1650 & 1517 \\
\hline $\begin{array}{l}\text { Rozliczanie otrzy- } \\
\text { manych i udziela- } \\
\text { nych dotacji }\end{array}$ & 92 & 163 & 188 & 283 & 593 & 789 & 750 & 781 & 615 \\
\hline Dług publiczny & - & - & - & - & 10 & 63 & 95 & 157 & 151 \\
\hline $\begin{array}{l}\text { Gospodarowanie } \\
\text { mieniem }\end{array}$ & 1254 & 1093 & 1338 & 1339 & 1372 & 1200 & 1171 & 1004 & 1051 \\
\hline $\begin{array}{l}\text { Rozliczenia JST } \\
\text { z jednostkami orga- } \\
\text { nizacyjnymi }\end{array}$ & 243 & 228 & 278 & 311 & 261 & 144 & 221 & 115 & 102 \\
\hline
\end{tabular}

Źródło: opracowanie własne na podstawie danych pochodzących z [Sprawozdania z działalności... 2006-2014].

W tabeli 1 przedstawiono dane dotyczące liczby przypadków ujawnionych nieprawidłowości w poszczególnych obszarach gospodarki finansowej JST.

Ustalenia kontroli wskazują także na naruszenia prawa w takich obszarach gospodarki finansowej JST, jak: udzielanie zamówień publicznych - 12\%, gospodarowaniem mieniem $-9 \%$, zarządzania długiem $-1 \%$, rozliczenia JST z jednostkami organizacyjnymi $-2 \%$. Zmniejszenie liczby naruszeń prawa w gospodarce finansowej JST jest możliwe po wdrożeniu stosownych mechanizmów kontroli. 


\section{Skutki finansowe nieprawidłowości}

Naruszenia prawa w gospodarce finansowej JST obrazują skalę finansową nieprawidłowości. Z danych zawartych w tabeli 2 wynika, że skutki finansowe ujawnionych nieprawidłowości w 2013 r. w stosunku do roku poprzedniego wzrosły aż o 9578 mln zł, a w 2014 r. w stosunku do 2013 r. - o $18582 \mathrm{mln}$ zł. Analizując strukturę skutków finansowych naruszeń prawa, uznać należy, że największe występują w obszarze księgowości i sprawozdawczości. Jeśli chodzi o nierzetelne rejestrowanie danych finansowych i gospodarczych w księgach rachunkowych lub nierzetelne wykazywanie tych danych w sprawozdawczości, ujawnione kwoty nieprawidłowości wynosiły od $3514 \mathrm{mln}$ zł $(71,6 \%)$ w $2011 \mathrm{r}$. do 32067 mln zł (97,7\%) w 2014 r. O tak dużej skali skutków finansowych w tym obszarze zdecydowało nierzetelne prowadzenie ksiąg rachunkowych. Chodzi tu głównie o zaniechanie prowadzenia wszystkich elementów tworzących księgi rachunkowe, tj.: dziennika, zestawienia obrotów i sald, kont analitycznych i wykazu składników aktywów i pasywów. Brak chociażby jednego z tych elementów jest niezgodny z wymaganiami określonymi w art. 13 ust. 1 ustawy o rachunkowości. Ponadto prawo bilansowe wymaga, aby księgi rachunkowe były prowadzone rzetelnie, bezbłędnie, sprawdzalnie i na bieżąco. Wykazywanie $\mathrm{w}$ sprawozdaniach danych niezgodnie $\mathrm{z}$ danymi wynikającymi z ewidencji księgowej również powoduje powstawanie tak wysokich skutków finansowych ujawnionych nieprawidłowości. Warto pokreślić, że zgodnie z dyspozycją art. 77 ustawy o rachunkowości nieprowadzenie ksiąg rachunkowych lub prowadzenie ich wbrew ustawie stanowi przesłankę do kary grzywny lub kary pozbawienia wolności do lat 2, albo obu tych kar łącznie. Natomiast sporządzanie nierzetelnych sprawozdań budżetowych, m.in. przez wykazywanie w nich nierzetelnych danych, generuje poważne ryzyko naruszenia dyscypliny finansów publicznych wynikającej z art. 18 ust. 2 Ustawy z dnia 17 grudnia 2004 r. o odpowiedzialności za naruszenie dyscypliny finansów publicznych. Szczegółową strukturę skutków finansowych nieprawidłowości w poszczególnych obszarach prezentuje tabela 2.

Wyniki analizy wskazują, że drugą grupą nieprawidłowości generującą wysokie skutki finansowe są naruszenia prawa ujawnione w obszarze zamówień publicznych: w 2011 r. $440 \mathrm{mln}$ zł (9\%), a w 2012 r. $230 \mathrm{mln}$ zł (4,9\%). Równie duże skutki finansowe wystąpiły w obszarze związanym z planowaniem budżetu (w 2012 r. $341 \mathrm{mln}-7,3 \%$ ) oraz realizacją dochodów budżetowych (w 2011 r. 176 mln zł - 3,6\%) i dokonywaniem wydatków budżetowych (w 2013 r. 1015 mln zł - 7\%). Katalog przyczyn ujawnionych nieprawidłowości oraz ich skutków finansowych jest dość szeroki. Do najważniejszych można zaliczyć:

- częste zmiany w regulacjach prawnych normujących działanie gospodarki finansowej JST. Niestabilność przepisów prawa finansowego czy prawa bilan- 
Tabela 2. Nieprawidłowości w ujęciu finansowym w latach 2011-2014

\begin{tabular}{|l|c|c|c|c|c|c|c|c|}
\hline \multirow{2}{*}{ Zagadnienia } & \multicolumn{2}{|c|}{2011} & \multicolumn{2}{c|}{2012} & \multicolumn{2}{c|}{2013} & \multicolumn{2}{c|}{2014} \\
\cline { 2 - 9 } & w mln zł & w \% & w mln zł & w \% & w mln zł & w \% & w mln zł & w \% \\
\hline Ogółem & 4902,2 & 100 & 4689,6 & 100 & 14267,6 & 100 & 32849,9 & 100 \\
\hline $\begin{array}{l}\text { Księgowość } \\
\text { i sprawozdaw- } \\
\text { czość }\end{array}$ & 3514,6 & 71,6 & 3603,5 & 76,8 & 11822,5 & 82,9 & 32067,2 & 97,7 \\
\hline $\begin{array}{l}\text { Ogólne zagadnie- } \\
\text { nia planowania } \\
\text { budżetu }\end{array}$ & 267,8 & 5,5 & 341,1 & 7,3 & 305,0 & 2,1 & 160,8 & 0,5 \\
\hline $\begin{array}{l}\text { Dochody budże- } \\
\text { towe }\end{array}$ & 176,1 & 3,6 & 79,3 & 1,7 & 91,6 & 0,6 & 73,5 & 0,2 \\
\hline $\begin{array}{l}\text { Wydatki budże- } \\
\text { towe }\end{array}$ & 149,2 & 3,0 & 175,8 & 3,6 & 1015,3 & 7,1 & 109,8 & 0,3 \\
\hline $\begin{array}{l}\text { Zamówienia } \\
\text { publiczne }\end{array}$ & 440,6 & 9,0 & 230,4 & 4,9 & 292,4 & 2,1 & 235,8 & 0,7 \\
\hline $\begin{array}{l}\text { Rozliczanie } \\
\text { dotacji }\end{array}$ & 111,8 & 2,3 & 40,3 & 0,9 & 57,2 & 0,4 & 36,8 & 0,1 \\
\hline Dług publiczny & 82,5 & 1,7 & 68,5 & 1,5 & 549,4 & 3,9 & 135,1 & 0,4 \\
\hline $\begin{array}{l}\text { Gospodarka } \\
\text { mieniem }\end{array}$ & 150,1 & 3,1 & 110,5 & 2,4 & 128,9 & 0,9 & 29,1 & 0,1 \\
\hline $\begin{array}{l}\text { Rozliczenia JST } \\
\text { z jednostkami } \\
\text { organizacyjnymi }\end{array}$ & 9,5 & 0,2 & 40,2 & 0,9 & 5,3 & 0,0 & 1,8 & 0,0 \\
\hline
\end{tabular}

Źródło: opracowanie własne na podstawie danych pochodzących z [Sprawozdania z działalności... 2011-2014].

sowego powoduje, że pracownicy stosujący na co dzień te przepisy mogą być niepewni ich interpretacji, a także niezgodności w zastosowaniu w działalności praktycznej. Na stan taki mają także wpływ luki w przepisach prawa oraz lakoniczne formułowanie przez ustawodawcę niektórych fragmentów w ustawach. Typowym przykładem jest definicja kontroli zarządczej zawarta w art. 68 ustawy o finansach publicznych;

- kwalifikacje i kompetencje kadry zarządzającej i pracowników JST. Powszechnie wiadomo, że o sukcesie realizowanych zadań i celów publicznych decyduje w dużej mierze personel. Ograniczenie nieprawidłowości w działaniu gospodarki finansowej JST może nastąpić, jeżeli osoby wykonujące poszczególne zadania będą posiadały stosowną wiedzę, umiejętności, a także doświadczenie pozwalające na efektywne i zgodne z wymogami prawa wypełnianie obowiązków służbowych. Według M. Kosek-Wojnar osoby, które będą sprawować władzę w różnych jednostkach samorządowych, obok kompetencji powinny posiadać 
określone predyspozycje - są to uczciwość, rzetelność, bezinteresowność, niezależność. Duże znaczenie ma także kryterium merytoryczne [Kosek-Wojnar i Surówka 2007, s. 136];

- poprawna struktura organizacyjna JST. Duży wpływ na minimalizowanie ryzyka nieprawidłowości w gospodarce finansowej jednostek samorządowych ma struktura organizacyjna. Powinna być ona dostosowana do założonych celów i zadań JST. W praktyce dobrym rozwiązaniem jest określenie dla każdego pracownika $\mathrm{w}$ formie pisemnej zakresu zadań i uprawnień dla komórek organizacyjnych będących w strukturze JST. Dużą rolę w ograniczeniu przyczyn powstawania nieprawidłowości odgrywa dostęp do informacji niezbędnych do podejmowania decyzji zarządczych. Dlatego też system komunikacji powinien zapewnić nie tylko przepływ informacji, ale także ich właściwe zrozumienie przez odbiorców (zob. szerzej [Komunikat nr 23... 2009]).

\section{Mechanizmy kontroli nieprawidłowości w gospodarce finansowej jednostek samorządu terytorialnego}

Problematykę mechanizmów kontroli należy rozpatrywać w kontekście poszczególnych grup standardów kontroli zarządczej dla sektora finansów publicznych, tj.:

- środowiska wewnętrznego,

- celów i zarządzania ryzykiem,

- mechanizmów kontroli,

- informacji i komunikacji,

- monitorowania i oceny.

Standardy określają podstawowe wymagania odnoszące się do funkcjonowania systemu kontroli zarządczej w sektorze finansów publicznych. Zasadniczym celem jest zaś promowanie spójnego i jednolitego modelu kontroli zarządczej zgodnie $\mathrm{z}$ międzynarodowymi wytycznymi w tym zakresie [Komunikat $\mathrm{nr} 23 . . .2009$ ]. Powszechnie mechanizmy kontroli określane są jako uregulowania wewnętrzne, które wspomagają działanie poszczególnych obszarów, ograniczając ryzyko nieprawidłowości, a także zapewniają prawidłową realizację celów. Dodać należy, że $\mathrm{w}$ obecnym stanie prawnym brak konkretnego przepisu w ustawie o finansach publicznych z 2009 r. zobowiązującego kierowników jednostek do opracowania w formie pisemnej procedur dotyczących m.in. przeprowadzania wstępnej oceny celowości zaciągania zobowiązań finansowych i dokonywania wydatków. Obowiązek ustalenia tych procedur w formie pisemnej wynikał $\mathrm{z}$ art. 47 ust. 3 ustawy o finansach publicznych z $2005 \mathrm{r}$. W aktualnych uregulowaniach prawnych ustawodawca w art. 68 ust. 2 wskazał tylko ogólnie, że celem kontroli zarządczej 
jest zgodność działania z procedurami wewnętrznymi. Można więc przyjąć, że mimo zmiany regulacji za właściwe uznaje się opracowanie uregulowań wewnętrznych w formie pisemnej (por. [Trykozko 2010, s. 160]). Ustalenie niektórych procedur tworzących system kontroli zarządczej wynika wprost z przepisów prawa. Przykładem obligatoryjnej procedury są zasady (polityka) rachunkowości obowiązek ich opracowania w formie pisemnej wynika wprost $\mathrm{z}$ dyspozycji art. 10 ust. 2 ustawy o rachunkowości. Dokumentacja ta jest kluczowa do prawidłowego działania systemu rachunkowości w JST. Opracowana zgodnie w wymogami prawa bilansowego skutecznie ogranicza ryzyko dysfunkcji w obszarze rachunkowości.

Z uwagi na specyfikę JST dobór mechanizmów kontroli powinien być starannie przemyślany, tak aby wdrożone procedury stanowiły odpowiedź na zidentyfikowane ryzyko i pozwalały nim elastycznie zarządzać. Opracowując mechanizmy kontroli, warto wykorzystać wytyczne i wskazówki zawarte w standardach kontroli zarządczej dla sektora finansów publicznych. W celu ograniczenia ryzyka nieprawidłowości w gospodarce finansowe JST można w szczególności wykorzystać takie rodzaje mechanizmów kontroli, jak (zob. szerzej [Komunikat nr 23... 2009]:

- dokumentowanie systemu kontroli zarządczej - procedury wewnętrzne, inne dokumenty określające zakres obowiązków, uprawnień i odpowiedzialności powinny być spójne i dostępne dla wszystkich osób;

- ochrona zasobów - należy zadbać, aby dostęp do zasobów JST miały wyłącznie upoważnione osoby;

- szczegółowe mechanizmy kontroli dotyczące operacji finansowych i gospodarczych - wymaga się, aby procedury zapewniały: rzetelne i pełne dokumentowanie i rejestrowanie operacji finansowych i gospodarczych, podział kluczowych obowiązków, zwłaszcza przy autoryzacji operacji finansowych, a także by przestrzegano zasady dokonywania weryfikacji operacji finansowych i gospodarczych przed realizacją i po realizacji;

- mechanizmy kontroli dotyczące systemów informatycznych - należy wdrożyć politykę bezpieczeństwa systemów informatycznych uwzględniającą w szczególności hasła dostępu, autoryzację zmian w systemach informatycznych itp.

Wprowadzając mechanizmy kontroli, należy kierować się zasadą, że koszt ich opracowania i wdrożenia nie powinien przekroczyć uzyskiwanych rezultatów.

\section{Podsumowanie}

Główny wniosek płynący z rozważań dotyczy dużej liczby ujawnianych przypadków naruszeń prawa w gospodarce finansowej JST. Największą liczbę nieprawidłowości ujawniono w obszarze związanym z planowaniem i realizacją budżetu samorządowego. Na drugim miejscu RIO wskazuje nieprawidłowości w zakresie 
systemu rachunkowości i sprawozdawczości. Dane te są niepokojące, gdyż może to świadczyć o słabościach związanych z zarządzaniem budżetem - z jednej strony z dysfunkcjami w pobieraniu, udzieleniu ulg i zwolnień w podatkach i opłatach lokalnych, a z drugiej z brakiem efektywności i racjonalnego dokonywania wydatków publicznych. Tak duża liczba nieprawidłowości w działaniu systemu rachunkowości i sprawozdawczości może w konsekwencji podważać wiarygodność użytecznej informacji płynącej ze sprawozdawczości budżetowej i finansowej. Zniekształcona informacja o sytuacji finansowej, chociażby zadłużeniu JST, a także faktycznie osiągniętych rezultatach, może wprowadzać w błąd odbiorców zewnętrznych i wewnętrznych. Ważne jest, aby decydenci samorządowi wyciągali wnioski z przedstawionych przez RIO ustaleń. Ograniczenie naruszeń prawa nastąpić może przez zapewnienie bieżących szkoleń pracownikom JST, gdyż ze względu na ciągłe zmiany regulacji prawa istnieje wysokie ryzyko powstawania nieprawidłowości. Ważnym czynnikiem przesądzającym o liczbie popełnianych błędów jest stabilność kadr w działach finansowo-księgowych. Liczba ujawnionych nieprawidłowości, a także ich wymiar finansowy dowodzą, że RIO ogrywają ważną rolę w procesie zarządzania JST i przyczyniają się do poprawy gospodarowania finansowymi środkami publicznymi.

\section{Literatura}

Chojna-Duch E. [2003], Polskie prawo finansowe. Finanse publiczne, LexisNexis, Warszawa.

Cybulski B. [2010], Geneza, ewolucja i istota funkcji kontrolnej Regionalnych Izb Obrachunkowych [w:] Regionalne Izby Obrachunkowe. Charakterystyka ustrojowa $i$ komentarze do ustawy, red. M. Stec, Wolters Kluwer, Warszawa.

Czerwiński K. [2003], Analiza ryzyka w audycie wewnętrznym, LINK, Szczecin.

Dębowska-Romanowska T. [2007], Wstęp [w:] Regionalne izby obrachunkowe, Krajowa Rada Regionalnych Izb Obrachunkowych, Warszawa.

Filipiak B. [2007], Miejsce i znaczenie kontroli gospodarki finansowej jednostek samorzqdu terytorialnego prowadzonej przez regionalne izby obrachunkowe [w:] 15 lat funkcjonowania regionalnych izb obrachunkowych, red. J. Małecki, R. Hauser, Z. Janku, Krajowa Rada Regionalnych Izb Obrachunkowych, Poznań.

Glosariusz terminów dotyczqcych kontroli i audytu w administracji publicznej [2005], Departament Strategii Kontrolnej NIK, Warszawa, www.nik.gov.pl (data dostępu: 2.02.2016).

Informacja o wynikach kontroli funkcjonowania kontroli zarządczej w jednostkach samorządu terytorialnego ze szczególnym uwzględnieniem audytu wewnętrznego [2011], LGD-4101-036/2011, nr ewid. 140/2011/P10132/LGD.

„Informator” [2007], Krajowa Rada Regionalnych Izb Obrachunkowych, Warszawa.

Jastrzębska M., Janowicz-Lomott M., Łyskawa K. [2014], Zarzqdzanie ryzkiem w dziatalności jednostki samorzqdu terytorialnego ze szczególnym uwzględnieniem ryzyka katastroficznego, Wolters Kluwer, Warszawa. 
Kałużny S., Zawadzak T. [1999], Kontrola gospodarcza w jednostkach budżetowych, Kwantum, Warszawa.

Kasiński M., Kamieciak Z., Kosikowski C., Krawczyk R.P. [1994], Ustawa o Regionalnych Izbach Obrachunkowych z komentarzem oraz teksty innych aktów prawnych, Municipium, Warszawa.

Komunikat nr 23 Ministra Finansów z dnia 16 grudnia 2009 r. w sprawie standardów kontroli zarządczej dla sektora finansów publicznych, Dz.Urz. Min. Fin. nr 15, poz. 84.

Kontrola zarządcza w jednostkach samorządu terytorialnego [2010], Pismo z dnia 29 stycznia 2010 r., DA6/4095/NWX/2010/775, Ministerstwo Finansów, Warszawa.

Kontrola zarzqdeza w jednostkach samorzqdu terytorialnego [2011], Biuletyn, nr 1, Ministerstwo Finansów, Warszawa.

Kosek-Wojnar M., Surówka K. [2007], Podstawy finansów samorzqdu terytorialnego, Wydawnictwo Naukowe PWN, Warszawa.

Kurowski L., Ruśkowski E., Sochacka-Krysiak H. [2000], Kontrola finansowa w sektorze publicznym, PWE, Warszawa.

Rozporządzenie Prezesa Rady Ministrów z dnia 16 lipca 2004 r. w sprawie siedzib i zasięgu terytorialnego regionalnych izb obrachunkowych oraz szczegółowej organizacji izb, liczby członków kolegium i trybu postępowania, Dz.U. 2004 nr 167 poz. 1747.

Sprawozdania z działalności regionalnych izb obrachunkowych i wykonania budżetu przez jednostki samorządu terytorialnego za lata 2006-2014 [2006-2014], Krajowa Rada Regionalnych Izb Obrachunkowych, Warszawa.

Trykozko R. [2011], Ustawa o finansach publicznych. Komentarz dla jednostek samorządu terytorialnego, Taxpress, Warszawa.

Uchwała nr 2/2001 Krajowej Rady Regionalnych Izb Obrachunkowych z 21 marca 2001 r. w sprawie ramowej tematyki kontroli kompleksowych jednostek samorządu terytorialnego, www.rio.gov.pl (data dostępu: 15.03.2016).

Ustawa z dnia 7 października 1992 r. o regionalnych izbach obrachunkowych, tekst jedn. Dz.U. 2012 poz. 1113.

Ustawa z dnia 29 września 1994 r. o rachunkowości, tekst jedn. Dz.U. 2015 poz. 4.

Ustawa z dnia 17 grudnia 2004 r. o odpowiedzialności za naruszenie dyscypliny finansów publicznych, tekst jedn. Dz.U. 2013 poz. 168.

Ustawa z dnia 30 czerwca 2005 r. o finansach publicznych, Dz.U. nr 249 poz. 2104.

Ustawa z dnia 27 sierpnia 2009 r. o finansach publicznych, tekst jedn. Dz.U. 2013 poz. 885.

Uzasadnienie do rządowego projektu ustawy o finansach publicznych z 2009 r., Druk Sejmowy nr 1181.

\section{Irregularities in the Financial Management of Local Government Units Disclosed by the Regional Chambers of Audit - Analysis for the Years 2006-2014 \\ (Abstract)}

The issue presented in the article refers to the disclosure of legal violations revealed by regional chambers of audit (RCA) as a result of financial audits of local government units. The article also assesses the financial implications of the various types of irregularities. Given the scale of the irregularities disclosed, the article addresses the concept of management control as a new category of financial goal. According to the assumptions 
of the legislature, this goal is to support the realisation of the aims and tasks of local government. Bearing in mind the desire to reduce risk factors generating the formation of irregularities, the article presents the essence of control mechanisms in the operation of financial management.

The article presents the violations most frequently disclosed by the RCA as regards the operation of the financial management of local governments. It offers a review of the literature and examines RCA activity reports prepared by the National RCA Board. A secondary analysis of the legislation was also carried out. The study covers the years 2006-2014, a period that saw financial law change profoundly.

Keywords: local government, financial control, regional chamber of audit, irregularity. 